\author{
전북 마이산 일대의 야외지질 교수-학습자료 개발 및 \\ 초등 교사들의 반응 \\ 노병섭 ${ }^{1} \cdot$ 양우헌 ${ }^{2, *} \cdot$ 조규성 ${ }^{2}$ \\ ${ }^{1}$ 전북대학교 과학교육학과, 561-756, 전북 전주시 덕진구 덕진동 664-14 \\ ${ }^{2}$ 전북대학교 과학교육학부/과학교육연구소/융합과학연구소, 561-756, 전북 전주시 덕진구 덕진동 664-14
}

\title{
The Responses of Elementary Teachers and the Development of Teaching Materials for Geological Fieldwork in the Area of Mai Mountain
}

\author{
Beyong-Seob Noh', Woo-Hun Ryang ${ }^{2, *}$, and Kyu-Seong $\mathrm{Cho}^{2}$ \\ 'Department of Science Education, Chonbuk National University, Jeonbuk 561-756, Korea \\ ${ }^{2}$ Division of Science Education/Institution of Science Education/Institution of Fusion Science, \\ Chonbuk National University, Jeonbuk 561-756, Korea
}

\begin{abstract}
The purpose of this study is to develop teaching materials for geological fieldwork around the area of Mai Mountain and to analyze the responses of elementary teachers as to the application of fieldwork. The site of geological fieldwork, Mai Mountain area, is located around the Maisan Provincial Park of Jinan-gun, Jeonbuk Province where a large-scale sedimentary succession in the era of Cretaceous is shown. It provides an easy access to distinct outcrops around the provincial park. The sequences reveal different kinds of sedimentary rocks and various sedimentary structures, and provide information of the lacustrine sedimentary environments of the Cretaceous. In addition, metamorphic rocks and structures formed at the margin of the basement and the basinal fault as well as a sedimentary sequence of the Quaternary formed in a modern fluvial stream are observable. A 4-step fieldwork procedure was applied to a group of 13 elementary teachers. Through questionnaire and interview, results showed that (a) the geological fieldwork and materials were effective to positively increase science teaching from the participating teachers, and that (b) there is a great need of the development of various fieldwork sites and teaching materials that promote active fieldwork for students to have their lived experience and knowledge gain. It is suggested that teacher education programs be able to provide active fieldwork for elementary inservice teachers to properly carry out a geological fieldwork for their students.
\end{abstract}

Keywords: geological fieldwork, elementary teacher, sedimentary succession

요 약: 본 연구는 마이산 일대의 야외지질 학습자료를 개발하고, 이 개발된 자료를 초등 교사들에게 적용하여 나타난 반응을 분석하였다. 야외지질 학습자료 개발 지역은 전북 진안군 마이산 도립공원 주변이며 규모가 큰 백악기 퇴적층이 공원 주변에 노두로 잘 나타나 있어 관찰하기가 용이하다. 이 퇴적층을 통해 다양한 종류의 퇴적암과 퇴적구조를 관찰 할 수 있으며, 백악기의 호수 퇴적환경을 이해할 수 있다. 또한 기반암과 분지 경계 단층의 형성과정에서 생성된 변성 암 및 변성구조와 현생 하천 주변의 제 4 기 하천 퇴적층도 관찰할 수 있다. 야외학습은 13 명의 초등 교사들에게 4 단계 의 절차로 적용되었다. 질문지와 면담을 통한 연구 결과, (a) 야외지질 학습과 학습자료가 교사들의 과학 수업을 긍정적 으로 증진시키는 데 매우 유용하였다는 반응을 얻었고, (b) 학생들의 인지 발달에 도움이 되는 체험학습이 활발하게 진 행될 수 있도록 다양한 학습장과 자료 개발이 필요하다는 반응도 얻었다. 그러므로 교육기관은 초등 교사들이 초등학생 들의 야외지질 체험학습을 적절히 수행할 수 있도록 야외활동과 관련된 연수 프로그램을 지속적으로 제공하는 것이 바 람직하다.

주요어: 야외지질 학습, 초등 교사, 퇴적층

*Corresponding author: ryang@jbnu.ac.kr

Tel: 82-63-270-2790

Fax: 82-63-270-2802 


\section{서 론}

피아제(Piaget)의 인지발달론에 의하면 초등학생들 은 대부분 구체적 조작기(7-11세)에 해당되는데, 구체 적 조작기의 주요 특징은 개인이 보고, 듣고, 느끼고, 만지고, 냄새 맡고, 맛을 보는 등 구체적인 경험을 토 대로 사고하는 것이다(교육과학기술부, 2009). 따라서 이 시기의 학생들은 직접적인 경험이 중요하며(서동 욱, 2004), 그러한 경험을 제공할 수 있는 가장 좋은 프로그램들 중 하나가 야외지질 학습이다. 특히 야외 지질 학습은 과학에 대한 긍정적 방향, 호기심 증가, 자연에 대한 이해를 증진시켜 잠재력을 표출시키고 비판적 사고를 향상 시켜준다(Manner, 1995). 따라서 초등학생의 인지 발달을 위해서 교사는 야외지질 학 습과 같은 다양한 경험을 제공할 필요가 있다.

과학은 기본 개념을 이해하고 과학적 탐구 능력과 태도를 함양하여 일상생활의 문제를 창의적이고 합리 적으로 해결하는데 필요한 과학적 소양을 기른다(교 육인적자원부, 2007). 이를 위해 초등과학의 대부분 은 탐구 과정 및 활동 위주로 구성되어 있다. 특히 지구과학 분야는 시간적, 공간적으로 규모가 큰 자연 환경을 대상으로 하기 때문에 야외 학습이 중요하다. 초등과학 교과에서 지질관련 단원은 주로 자연환경을 다루며 대부분이 탐구활동으로 이루어져 있다. 초등 학생들에게 과학수업은 흥미와 호기심 및 과학적 사 고력을 자극하며(허명, 1993), 특히 야외지질 체험학 습은 과학적 태도를 향상시키는데 도움이 된다(조규 성 외, 2002). 초등 과학수업에서는 발견 및 확인실 험수업이 주요 유형이고 실험접근 방법은 귀납적인 형태가 많은데(양일호 외, 2007), 지질관련 탐구 활동 은 주로 귀납적 방법으로 이루어져 있다. 야외 지질 학습은 교실에서 경험할 수 없는 물질과 현상을 관 찰하고 직접 경험할 수 있는 기회를 제공하고(Orion, 1989), 교실에서 학습한 구체적인 예를 제공하여 교 육과정을 촉진시키는 중요한 체험활동이다(맹승호 외, 2007). 특히 지질관련 단원의 학습은 학생들에게 관심과 흥미를 불러일으킬 수 있고, 쉽게 접근할 수 있는 곳을 중심으로 야외 학습 자료를 개발하여 현 장체험이나 동아리활동을 진행하는 것이 효과적이다 (박재문 외, 2007).

전북 진안군에 위치한 마이산은 자연경관이 빼어나 전국적으로도 유명한 곳이고, 거대한 규모의 역암으 로 구성된 산이며 다양한 노두가 분포되어 있어 야
외지질 체험학습을 실시하기에 적절한 장소이다. 초 등학교에서는 일 년에 한두 번 현장 체험학습을 실 시하고 있지만 대부분의 경우 관광 위주의 활동에 그치고 있다. 그 원인은 야외지질에 대한 초등 교사 들의 배경지식이 부족하여(조현준 외, 2008), 체험학 습을 과학적 탐구 활동으로 연결시키지 못하고 있기 때문이다. 이는 초등 교사들이 대학 교육 과정 및 교 사 연수 과정에서 지질학과 같은 교과목 이수가 불 충분하고, 야외지질 학습 및 실습이 수행되지 못하고 있기 때문이다. 따라서 교육기관에서는 야외지질 학 습자료와 체험학습장을 개발하여 초등교사들에게 안 내하고, 실제적인 내용과 방법으로 연수를 실시해야 한다(곽영순, 2003). 이와 같이 개발된 학습장에서 교 사들이 야외지질을 풍부하게 경험 한다면 학생들에게 다양한 방법으로 야외지질 체험학습을 실시할 수 있 을 것이다. 본 연구는 전북 진안군 마이산 일대의 지 층 및 현생 퇴적층, 지질구조 등을 중심으로 야외지 질 학습자료 및 체험학습장을 개발하고, 이를 초등학 교 교사들에게 적용하였고 야외지질 체험학습에 대한 초등학교 교사들의 반응을 고찰하였다.

\section{연구 대상 및 연구 절차}

\section{연구 대상}

본 연구는 전북 전주시 소재 초등학교 3-6학년 담 임을 맡고 있는 13 명의 교사를 대상으로 야외지질 체험학습장에서 탐사 활동을 실시하고 반응 결과를 정리하였다. 교사들은 남자 1 명, 여자 12 명이며, 나이 는 20대 2명, 30대 7명, 40 대 4명이다. 교육경력은 4-6년 2명, 7-10년 6명, 10년 이상 5명이다. 초등교사 들의 지질관련 내용에 대한 지식과 야외지질 조사 경험, 수업 진행의 실태 등을 파악하여 야외지질 학 습자료 개발과 탐사 활동에 활용하기 위하여 설문조 사와 면담을 실시하였다. 설문조사와 면담의 주요 내 용은 고등학교와 대학교 재학시절 지구과학과목 이수 여부, 야외지질 탐사 경험, 지질관련 수업에서 어려 운 점 등에 관한 문항을 만들어 설문을 실시하였고, 보다 구체적인 내용은 면담을 통해 보완하였다. 본 연구자가 초등학교 교과서 분석 결과와 초등학교 교 사 13 명의 과학 수업 실태에 관한 의견을 듣고, 지구 과학교육과 박사학위 수료자 3 명이 토의를 거쳐 설 문지를 작성하였다.

설문조사 및 면담 결과 13 명의 교사는 고등학교에 
서 지구과학을 이수하였으나, 13 명 모두 지질탐사 관 련 연수를 받은 경우가 없었으며, 3명의 교사만이 야 외지질 탐사를 실시했거나 야외에서 지층을 관찰한 경험을 가지고 있었다. 퇴적암 분류에 대해 이암은 10 명, 사암 12 명, 역암 13 명, 석회암 4 명이 구분할 수 있다고 하였으나, 응회암은 응답자가 없었다. 화 성암에 대해서 현무암은 11 명, 유문암 3 명, 화강암은 12 명이 구분할 수 있다고 하였으나, 안산암은 응답자 가 없었다. 변성암에 대해서는 점판암은 1 명, 편암 3 명, 편마암 7 명, 대리암 10 명이 구분할 수 있다고 하 였으나 규암은 응답자가 없었다. 대부분의 교사가 이 암, 사암, 역암의 퇴적암을 구분할 수 있었고, 화성암 의 경우 현무암과 화강암은 분류할 수 있었으며, 변 성암은 대리암이나 편마암을 구분할 수 있었다.

초등 과학 교과서 지구과학 지질관련에서는 초등 교사들이 수업하기 가장 어려운 단원이나 내용으로 13 명 중 7 명은 암석관련 단원에, 4 명은 지층의 어긋 남과 휘어짐에 대한 내용을 선택하였다. 또한 아이들 을 인솔하여 야외지질 체험학습을 할 수 있는 장소 중에서 9 명의 교사는 마이산으로, 4 명의 교사는 격포 채석강으로, 3 명의 교사는 두 곳 모두 현장 체험학습 을 다녀온 경험도 있었다.

\section{연구 절차}

이 연구는 기존 연구의 야외지질 학습모형(맹승호, 2004; 박재문 외, 2007)과 논문(이병주 외, 2005; 박 경화 외, 2007; Lee, 1995)을 참조하고 본 연구자가 수정 보완하여 네 단계의 절차로 진행하였다(Fig. 1). 실시 기간은 2009년 1월부터 2009년 10월까지 초등 학교 및 마이산 일대 야외지질 체험학습장에서 진행 하였다.

자료 및 교과서 분석: 초등학교 교육과정 운영과 과 학 교과서의 지질관련 단원을 분석하였다. 7차 교육 과정에서 '과학'은 3학년(초등학교 3학년)부터 10 학 년(고등학교 1 학년)까지 국민 공통 기본 교육과정을 두어 과학적 소양을 기르기 위하여 자연을 과학적으 로 탐구하는 능력과 기본 개념을 습득하고, 과학적인 태도를 기르기 위한 과목이다. 과학의 내용은 에너지, 물질, 생명, 지구 등의 지식과 탐구과정 및 탐구활동 으로 이루어졌으며, 3 학년부터 5 학년까지는 기본 과 정으로, 6 학년부터 10 학년까지는 기본과정과 기본과 정에 근거한 심화 - 보충 과정으로 구성되어 있다. 초

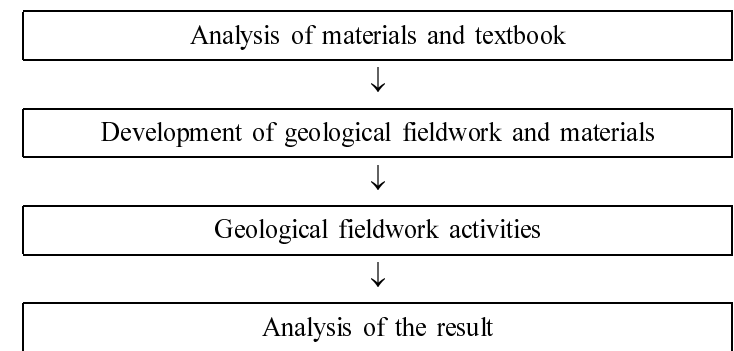

Fig. 1. The 4-step procedure of geological fieldwork.

등 과학교과 내용의 대부분이 학생활동 중심의 탐구 과정 및 탐구활동으로 구성되어 있다. 지구과학 지질 관련 단원은 훍을 나르는 물, 여러 가지 돌과 훍, 지 층을 찾아서, 화석을 찾아서, 화산과 암석, 지진, 여러 가지 암석 등 7개 단원이다(교육인적자원부, 2007; 교 육과학기술부, 2009).

야외지질 체험학습장 및 자료 개발: 설문 조사 및 면 담을 토대로 진안분지 북동부에 위치한 마이산 일대 다섯 곳을 야외지질 체험학습장으로 선정하고 자료를 만들었다. 마이산은 관광지로도 접근하기 쉽고, 신비 스러운 돌탑 등이 있어 학생들에게 호기심과 흥미를 제공할 수 있고 학습 효과에도 긍정적인 영향을 미 칠 수 있는 적절한 장소이기 때문이다. 이 학습장에 서는 퇴적암의 종류와 퇴적구조, 퇴적 당시 환경, 암 석의 이용, 풍화와 침식, 화석, 현생 퇴적층, 퇴적분 지 등을 체험할 수 있다. 초등 과학 교과서 지구과학 의 지질관련 내용 중에서 마이산 일대 체험학습장에 서 학습 할 수 있는 내용은 Table 1과 같다.

야외지질 탐사 활동: 야외지질 탐사를 실시하기 전에 초등 과학교과서를 분석하여 다양한 지질관련 심화 내용과 마이산 일대 체험학습장 등에 대해 본 연구 자가 1 회에 걸쳐 3 시간의 수업을 진행하고, 야외지질 탐사 활동을 실시하였다. 탐사 활동의 진행은 각 체 험학습장에 도착하면 먼저 학습장을 살펴보게 한 다 음 참가교사들이 관찰한 내용을 먼저 이야기하도록 하였다. 그 다음 참여교사와 연구자 간의 질의와 응 답이 이루어졌으며, 마지막으로 참가자들이 연구자로 부터 체험학습장의 전반적인 지질관련 내용에 관한 설명을 들으면서 보고서를 작성하였다.

결과 분석: 야외지질 탐사 활동을 마치고 교사들이 작성한 보고서와 소감을 듣고, 관찰한 내용과 체험학 
Table 1. Analysis of elementary textbook related to geology (Ministry of education, science and technology, 2009)

\begin{tabular}{|c|c|c|c|c|c|}
\hline \multirow{2}{*}{ Grade } & \multirow{2}{*}{ Chapter } & \multirow{2}{*}{ Topic } & \multirow{2}{*}{ Knowledge } & \multicolumn{2}{|c|}{ Search } \\
\hline & & & & Search process & Search activity \\
\hline \multirow{2}{*}{$3-1$} & \multirow{2}{*}{$\begin{array}{l}\text { 8. Water } \\
\text { carrying soil }\end{array}$} & $\begin{array}{l}\text { Comparison of the aspect of } \\
\text { soil before and after heavy rain }\end{array}$ & Trimmed, carried and stacked soil & Observation & $\begin{array}{l}\text { Examination, } \\
\text { Discussion }\end{array}$ \\
\hline & & $\begin{array}{l}\text { Comparison of the aspect of } \\
\text { soil by flowing water }\end{array}$ & $\begin{array}{l}\text { Change of watercourse and } \\
\text { soil surface }\end{array}$ & Observation & Experiment \\
\hline \multirow{5}{*}{$3-2$} & \multirow{5}{*}{$\begin{array}{l}\text { 5. Various } \\
\text { stones and } \\
\text { soils }\end{array}$} & $\begin{array}{l}\text { Observation and classification } \\
\text { for various stones }\end{array}$ & Where to be stones & $\begin{array}{l}\text { Observation, } \\
\text { Classification }\end{array}$ & \\
\hline & & $\begin{array}{c}\text { Naming stones and making a letter } \\
\text { of introduction }\end{array}$ & Variety of stones & $\begin{array}{l}\text { Observation, } \\
\text { Communication }\end{array}$ & \\
\hline & & $\begin{array}{l}\text { Searching for the process of } \\
\text { forming soil }\end{array}$ & Formation process of soil & $\begin{array}{l}\text { Observation } \\
\text { Inference }\end{array}$ & \\
\hline & & Use of stone, sand and soil & Use of stone, sand and soil & Observation & Examination \\
\hline & & $\begin{array}{l}\text { Searching houses made with stone } \\
\text { and soil }\end{array}$ & Use of stone and soil & $\begin{array}{l}\text { Observation, } \\
\text { Inference }\end{array}$ & \\
\hline \multirow{8}{*}{$4-2$} & \multirow{4}{*}{$\begin{array}{l}\text { 3. Looking for } \\
\text { strata }\end{array}$} & Observation of the shape of strata & Definition of stratum & $\begin{array}{l}\text { Observation, } \\
\text { Communication }\end{array}$ & $\begin{array}{l}\text { Examination, } \\
\text { Discussion }\end{array}$ \\
\hline & & Oder of strata's stacking & $\begin{array}{l}\text { Oder and thickness of strata's } \\
\text { stacking }\end{array}$ & Inference & $\begin{array}{l}\text { Examination, } \\
\text { Experiment }\end{array}$ \\
\hline & & Process of strata forming & $\begin{array}{l}\text { Formation process of strata, } \\
\text { deposits and sedimentary rock }\end{array}$ & Observation & Experiment \\
\hline & & Observation of fragments of strata & mudstone, sandstone, conglomerate & $\begin{array}{l}\text { Observation, } \\
\text { Classification, } \\
\text { Inference }\end{array}$ & Examination \\
\hline & \multirow{4}{*}{$\begin{array}{l}\text { 4. Looking for } \\
\text { fossil }\end{array}$} & Observation of fossil & Definition of fossil & $\begin{array}{l}\text { Observation, } \\
\text { Classification }\end{array}$ & $\begin{array}{l}\text { Examination, } \\
\text { Discussion }\end{array}$ \\
\hline & & Making a model of fossil & Principle of formation of fossil & $\begin{array}{c}\text { Observation, } \\
\text { Formation of model }\end{array}$ & Experiment \\
\hline & & $\begin{array}{l}\text { Process of formation and } \\
\text { discovery of fossil }\end{array}$ & Process of formation of fossil & $\begin{array}{c}\text { Inference, } \\
\text { Formation of model }\end{array}$ & $\begin{array}{l}\text { Discussion, } \\
\text { Experiment }\end{array}$ \\
\hline & & Use of fossil & Where to use fossil & $\begin{array}{l}\text { Observation, } \\
\text { Classification, } \\
\text { Inference }\end{array}$ & $\begin{array}{l}\text { Examination, } \\
\text { Discussion }\end{array}$ \\
\hline $5-2$ & $\begin{array}{l}\text { 4. Volcano and } \\
\text { rocks }\end{array}$ & $\begin{array}{l}\text { Searching for rocks made by } \\
\text { volcanic activity }\end{array}$ & $\begin{array}{l}\text { Magma, igneous rocks, lava, } \\
\text { granite, basalt, etc. }\end{array}$ & $\begin{array}{l}\text { Observation, } \\
\text { Discussion }\end{array}$ & \\
\hline \multirow{4}{*}{$6-1$} & 2. Earthquake & Strata's bending and crossing & Fold, fault & Experiment & \\
\hline & \multirow{3}{*}{$\begin{array}{l}\text { 4. Various } \\
\text { rocks }\end{array}$} & Metamorphosis of rocks & Metamorphosis, metamorphic rock & $\begin{array}{l}\text { Experiment, } \\
\text { Observation }\end{array}$ & $\begin{array}{l}\text { Examination, } \\
\text { Comparison }\end{array}$ \\
\hline & & Characteristics of metamorphic rock & gneiss, gneiss structure & $\begin{array}{l}\text { Experiment, } \\
\text { Observation }\end{array}$ & Comparison \\
\hline & & Use of various rocks & Characteristics and use of rocks & $\begin{array}{l}\text { Data collection and } \\
\text { analysis }\end{array}$ & $\begin{array}{l}\text { Examination, } \\
\text { Group activity }\end{array}$ \\
\hline
\end{tabular}

습 등에 관해 의견을 나누고 결과를 정리하였다. 또 한 탐사 활동을 다녀 온 후 지질관련 과학 수업에서 활용과 야외지질 체험학습의 중요성, 체험학습 활성 화 방안, 다양한 야외지질 체험학습장 및 자료 개발, 지속적인 연수 등에 관한 설문을 실시하고 그 결과 를 분석하였다.

\section{마이산 일대 야외지질 체험학습장}

\section{야외지질 체험학습장 안내}

진안분지의 북동쪽에 위치한 마이산 일대는 다양한 퇴적암과 퇴적구조, 퇴적환경 등을 관찰할 수 있다. 본 체험학습장은 백악기 당시 퇴적 분지의 경계부에 


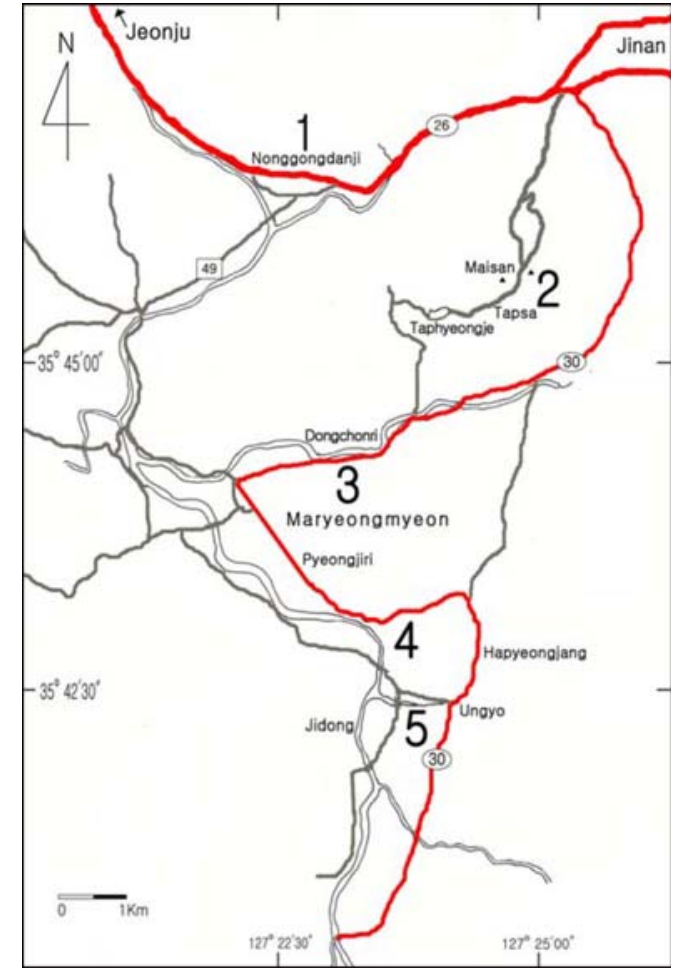

Fig. 2. Road map and location of the study area. Numbers 1 to 5 show the observation sites and the numerals in a circle and a rectangle represent national and local roads, respectively.

해당되는 마이산 역암층, 경계에서 분지 안쪽으로 들 어온 역질 사암이나 사암층의 경사면 지역 그리고 암회색의 이암이 관찰되는 분지 중앙부까지 퇴적 구 조 및 환경을 탐사하고, 재구성해 볼 수 있는 곳이다. 또한 퇴적분지의 하부 역암의 역의 공급원인 기반암 과 분지 경계 단층의 형성과정에서 생성된 변성암, 지각변동에 의한 지질구조, 화석, 현생 퇴적층 등을 관찰할 수 있다. 마이산 일대의 체험학습장은 여건에 따라 적절한 경로를 선택하여 실시할 수 있다(Fig. 2). 본 학습장은 접근하기 쉽고, 깨끗한 노두가 비교 적 잘 나타나 있다.

\section{지구조 및 지질 개요}

한반도의 남동부에는 백악기 퇴적암 및 화산암류로 채워진 경상분지가 위치하며, 중남부에는 북북동-남 남서로 발달하는 옥천대의 주변부를 따라 백악기 소 규모 퇴적분지들이 발달해 있다(Chough et al., 2000;
Fig. 3). 옥천대의 남쪽 주변부에는 영동분지, 무주분 지, 진안분지, 능주분지 및 해남분지 등이 발달해 있 으며, 북쪽 주변부에는 풍암분지, 음성분지, 공주분지, 부여분지 및 격포분지 등이 분포한다. 이 소분지들은 북동내지 북북동 방향으로 발달하는 주향이동 단층들 과 한쪽 또는 양쪽으로 분지경계를 형성하고 있다. 경상분지 및 소분지들의 지구조 형성 모델에 따르면 백악기 초기 동안 북동-남서 방향으로 소규모 좌수향 주향이동 분지들이 한반도 중남부에 형성되었다 (Chun and Chough, 1992). 이후 백악기 후기 동안 판의 이동방향의 전환에 따라 이들 분지들은 압축성 구조 운동을 받게 되었다.

경상분지의 퇴적환경은 분지 경계부에서 충적선상지 가 형성되어 하류로 갈수록 충적 평야를 지나 분지 중 심부의 호수 환경으로 전이되었다(Choi, 1986). 단속적 인 화산활동은 지역적으로 화산쇄설암류의 퇴적과 함 께 화산암류들의 분출 및 관입을 발생시켰다. 비슷한 시기 동안 광주 및 공주 단층대를 따라 발달한 소규모 의 주향이동 퇴적분지들도 분지 경계에서 분지 중앙부 로 퇴적상 전이를 보인다(Ryang and Chough, 1999; 유인창 외, 2000; Ryang, 2005). 진안분지는 북동-남 서 방향으로 발달한 주향이동 단층운동으로 형성된 주향이동 퇴적분지이다(Fig. 3). 진안분지 퇴적층은 옥천대 남부인 전주, 임실 및 진안 지역에 분포하고 있으며, 이 분지를 구성하는 진안층군은 육성퇴적물 이며, 중생대 백악기에 형성되었다(Shimamura, 1925; 홍만섭 외, 1966; 손치무, 1969; 김규봉 외, 1984; 이 영엽, 1992). 마이산은 진안분지의 북동쪽 경계에 위 치하는 두꺼운 역암 퇴적층이다(Lee and Chough, 1999). 진안 분지의 퇴적 환경은 화산 활동의 영향을 받지 않은 전기 단계와 화산 활동의 영향을 받은 후 기 단계의 두 시기로 구분될 수 있다. 전기 단계 분 지 퇴적층은 주로 분지 경계부를 따라 노출되어 있 는데, 퇴적층의 경사가 크며 일부 퇴적층은 습곡구조 를 보인다. 이는 주로 분지 경계부에 인접한 퇴적층 이 분지 구조운동의 영향을 크게 받았음을 보여준다. 역암층은 마름모 모양인 분지의 북쪽 경계부에 북동남서 방향으로 길게 분포하며, 마이산은 이 분지 북 동쪽 끝 모서리에 위치한다(Fig. 4). 분지의 중앙부에 는 사암층과 암회색 이암층이 주로 분포하며, 이는 퇴적 당시 분지 중앙부가 주로 호수 환경이었음을 알려준다. 


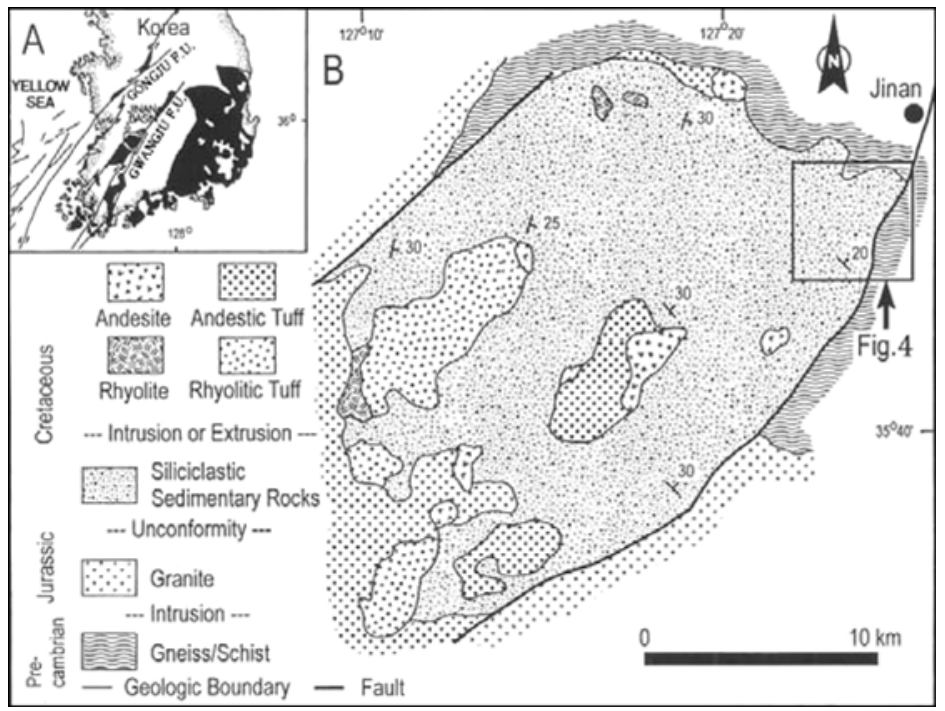

Fig. 3. (A) Distribution of the Cretaceous basins (solid areas) and major fault pattern in the southern Korean Peninsula. Solid arrows show the main direction of fault movement. Boxed area indicates the northem part of the Jinan Basin. (B) Geologic map of the northem part of the Jinan Basin. Detailed geologic map of the study area (boxed area) is shown in Fig. 4 (Modified after Korea Institute of Energy and Resources, 1984; Chun and Chough, 1992; Baag and Bagg, 1994; Kim and Kee, 1994; Korea Institute of Geology, Minning and Materials, 1995; Lee and Chough, 1999).

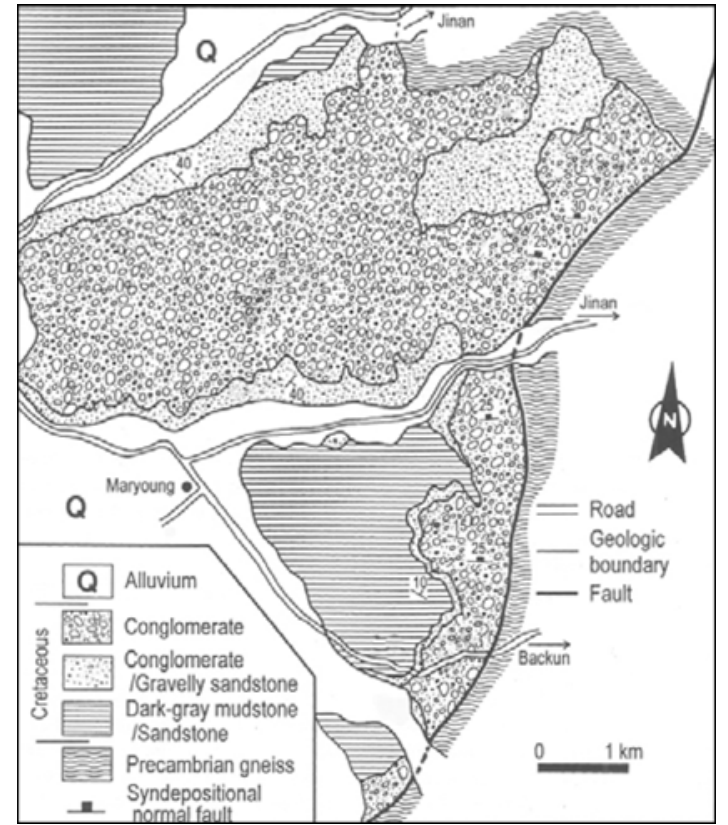

Fig. 4. Lithofacies map of the northeastern part of the Jinan Basin (Lee and Chough, 1999).

\section{관찰지점별 학습내용}

\section{관찰지점 $1:$ 거북이바위의 퇴적암 및 지질구조 (N35 46'10.5", E127²2'44.6")}

전주에서 진안 방향으로 26 번 국도변에 진안농공 단지가 있는데, 이 지역에서 거북이 형상을 닮은 거 북이바위가 나타난다. 이 거북이바위는 어미 거북이 와 새끼 거북이의 형상으로 이루어져 있다. 새끼 거 북이는 역암으로, 어미 거북이의 머리와 몸통 위 부 분은 역암으로, 몸통 아래 부분은 사암 및 셰일, 꼬 리 부분 아래에서는 기반암인 편암으로 구성되어 있 다. 어미거북이의 목 부분은 정단층으로 절단되어 있 으며(Fig. 5), 단층면에서는 단층점토(Fig. 6a)와 단층 경면(Fig. 6b)을 관찰할 수 있다. 이곳의 역암은 기질 조직에 사질이 거의 없이 주로 이질로 채워진 기질 지지 역암(matrix-supported conglomerate)을 관찰할 수 있는데, 이는 마이산 부근의 기질 조직에 이질이 거의 없이 사질로만 채워진 역지지 역암(clastsupported conglomerate)과 구별하여 관찰할 수 있다. 역암은 규암, 편암, 편마암 등의 역으로 구성되어 있 

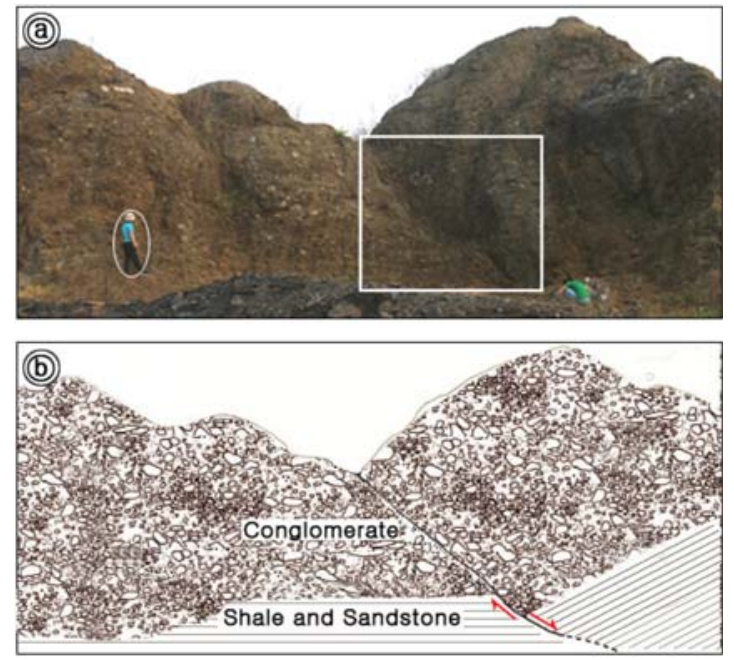

Fig. 5. Photograph (a) and line drawing (b) of sedimentary succession at the turtle rock of site 1 . Detailed photographs of boxed area are shown in Fig. 6. Scale for a person.

으며, 분급이 불량하고 원마도가 좋지 않다. 셰일층 은 엽층리와 층리가 잘 발달해 있고 나무줄기 화석 이 다수 포함되어 있으며, 사암층은 셰일층 사이에 얇게 협재되어 있다(Fig. 6d).
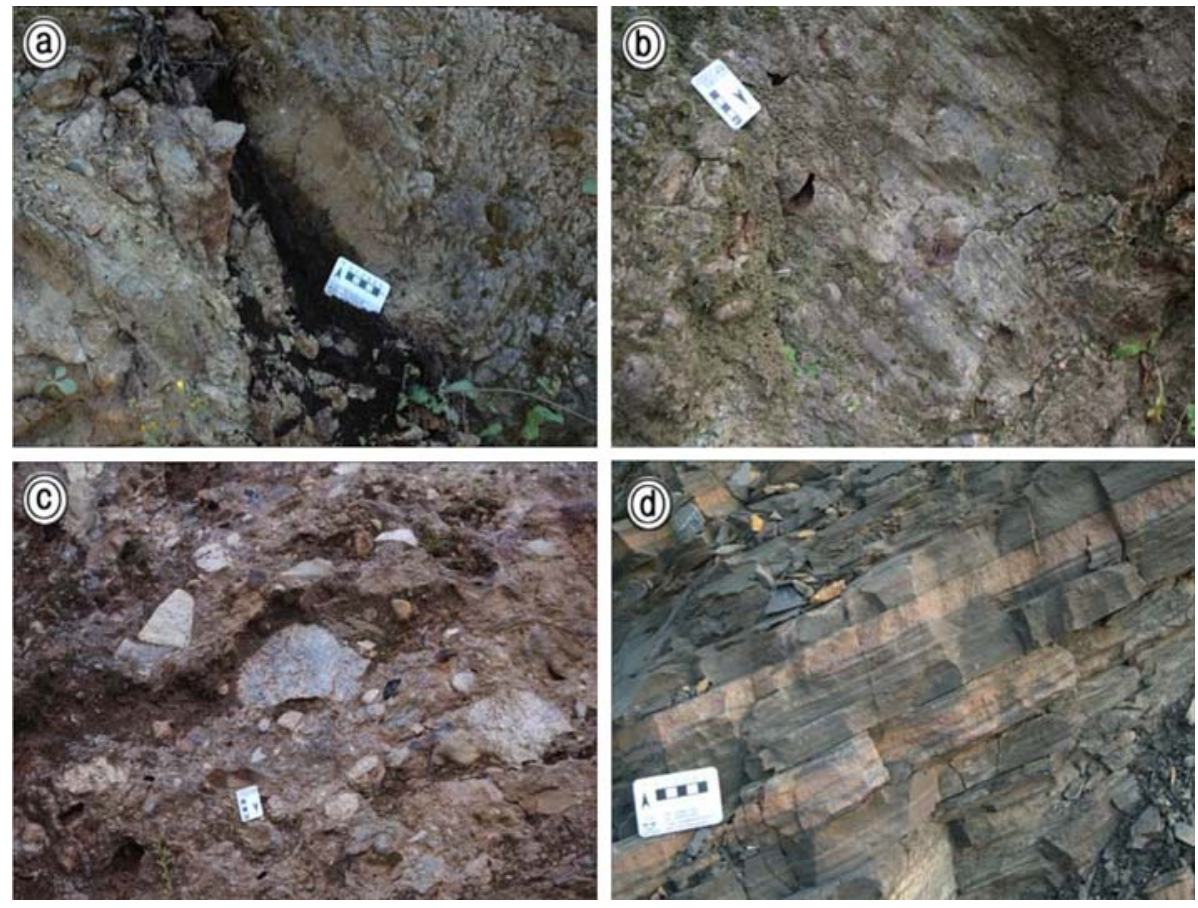

Fig. 6. Detailed photographs in the boxed area of Fig. 5. (a) Fault plane with gouge. (b) Distinctly stepped slickenside with striation. (c) Crudely stratified poorly-sorted conglomerate. (d) Distinctly bedded and laminated sandstone and shale. Scale for a 8$\mathrm{cm}$ rule.

\section{관찰지점 2: 탑사 주변의 퇴적암 및 퇴적 구조}

탑사 주변에 들어서면 약 $100 \mathrm{~m}$ 이상의 두께로 쌓 인 역암층이 나타나는데, 이 층은 주로 거력과 사질 퇴적물이 우세한 역암으로 구성되어 있다. 이 주변에 는 크고 작은 80 여 개의 돌탑이 있다. 이곳에서 마이 산의 형성과정을 살펴 볼 수 있다. 그리고 타포니의 형성 및 진행과정, 역의 크기와 종류, 층리면, 돌의 이용, 절리면을 따라 일어나는 풍화와 침식 지형 등 을 관찰할 수 있다.

역암의 층리면(N35 $\left.45^{\prime} 19.1^{\prime \prime}, \mathrm{E} 127^{\circ} 24^{\prime} 47.5^{\prime \prime}\right)$ : 퇴적암 의 대표적인 특징이 층리인데, 역암에서 층리를 관찰 하는 것은 쉽지 않다. 미륵존불 옆 절벽을 비스듬히 관찰하면 역들이 일정한 방향성을 가지고 늘어서 있 는 것을 볼 수 있다. 이것이 역암에서 나타나는 층리 면(bedding plane)이다(Fig. 7).

역암 및 역의 종류와 크기(N3545'20.4", E127 24'29.7"): 대웅전 옆 절벽을 보면 아주 다양한 종류, 크기 및 모양의 역으로 형성된 거대한 역암층을 관찰할 수 있다. 역의 직경은 $3 \mathrm{~cm}$ 에서 무려 $1 \mathrm{~m}$ 정도에 이른다. 

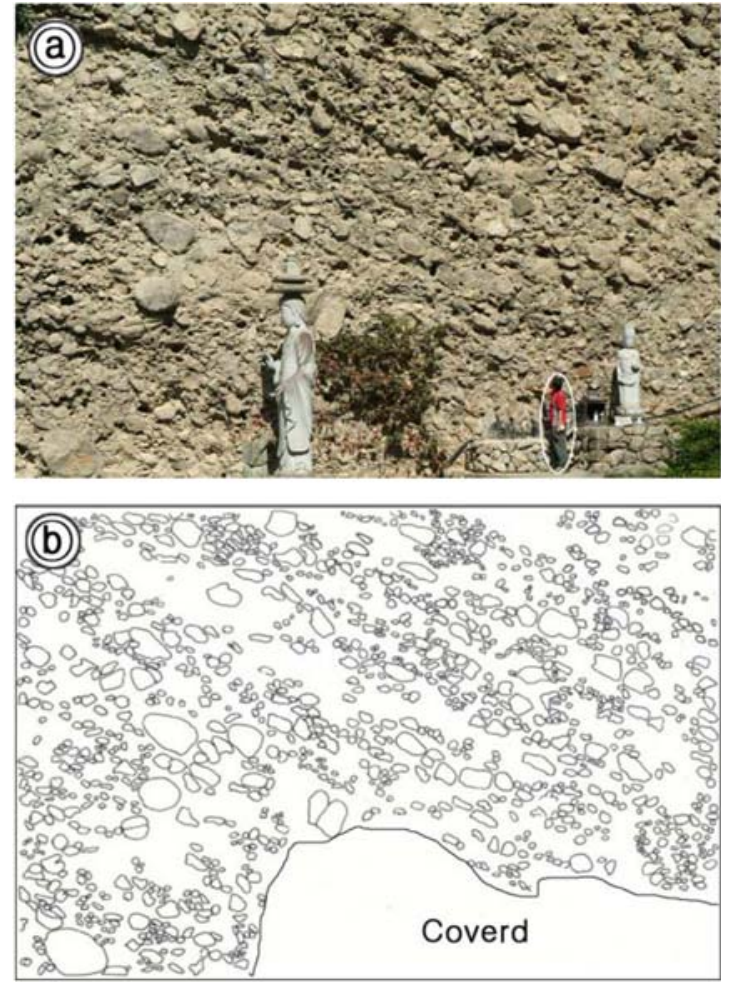

Fig. 7. Photograph (a) and sketch (b) of pebble- to bouldergrade, clast-supported disorganized, crudely stratified conglomerates. Note the amalgamated conglomerate beds and parallel-oriented clast fabric to bedding plane. Scale for a person.

역은 분급이 불량하고, 원마도가 좋지 않으며, 규암, 편암, 편마암 및 화강편마암 등 다양하다(Fig. 8). 역 이 빠져나간 '차별침식' 구조가 보이기도 한다. 이곳 의 역암은 역지지 역암(clast-supported conglomerate) 으로, 기질은 주로 사질이며 이질은 거의 관찰할 수 없다.

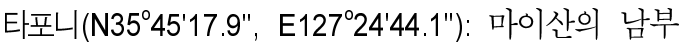
역암층에서는 차별침식에 의한 거대한 벌집 모양을 하고 있는 타포니(tafoni)를 볼 수 있다(Fig. 9). 타포 니는 처음에 역이 하나 빠져나가면 그 주변부가 약 해지고 계속해서 이웃에 있는 역들이 빠져나가면서 형성되며, 오랜 시간이 경과하면 거대한 타포니가 생 성된다. 타포니가 생성되는 원인은 긴 세월동안 기온 의 변화와 관계가 있는 것으로 추정할 수 있다. 결빙 과 해빙이 반복되는 풍화 과정에서 역암을 구성하고 있던 역이 떨어져 나온다. 이 과정이 계속 반복되면

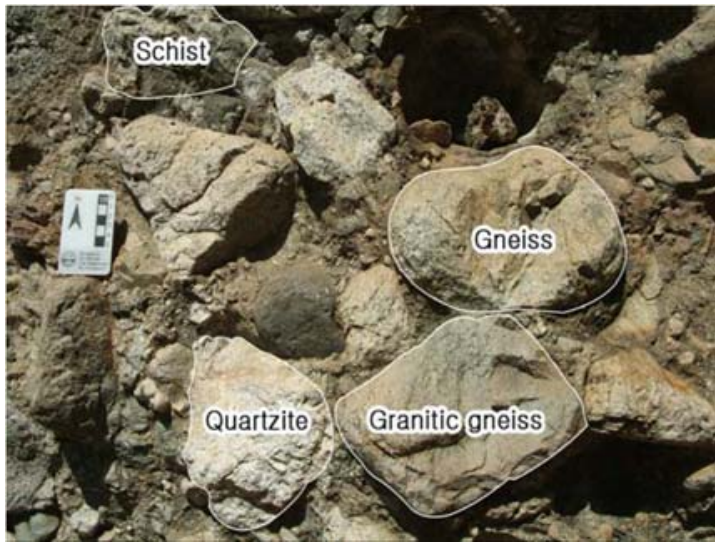

Fig. 8. Photograph of pebble- to boulder-grade, clast-supported disorganized, conglomerates. Note the various clast composition such as gneiss, granitic gneiss, quartzite, and schist. Scale for a 8-cm rule.

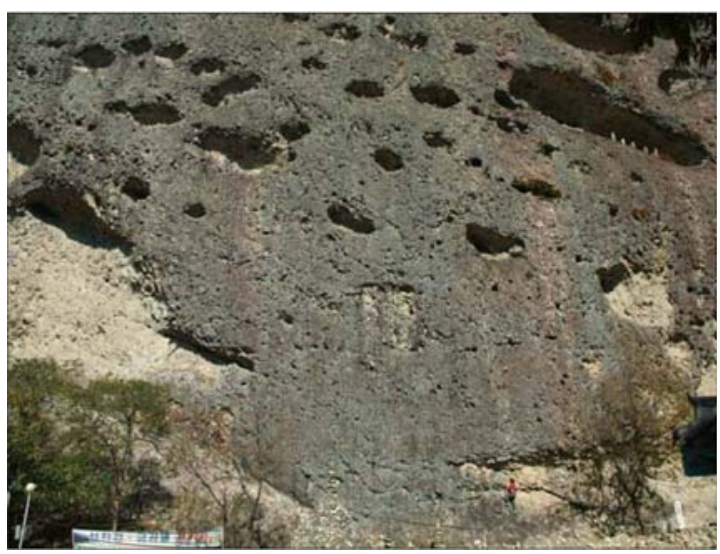

Fig. 9. Photograph of tafoni showing small- to large-scale cavities in mountain cliff. This is on the southern side of the Mai Mtn. Scale for a person.

주변의 역들도 떨어져 나와 점차 구덩이가 커져 현 재와 같은 모습으로 나타날 것이다.

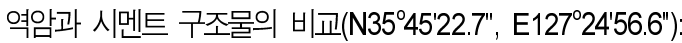
탑사를 지나 화엄굴로 가는 도중 은수사가 나오는데, 그 앞 절벽에는 층리면과 나란하게 발달한 절리를 따라 풍화가 진행되면서 형성된 거대한 타포니가 있 다. 이에 반해 커지고 있는 타포니의 붕괴를 막기위 해 시멘트로 채워 넣은 인공 구조물을 볼 수 있다. 이곳에서 인공 시멘트와 자연에서 형성된 역암의 특 징을 비교해 볼 수 있다. 
절리면를 따라 진행되는 풍화와 침식(N35 $45^{\prime} 18.7^{\prime \prime}$, $\left.\mathrm{E} 127^{\circ} 24^{\prime} 47.1^{\prime \prime}\right)$ : 탑사 입구 가게에서 암마이산을 바라 보면 층리면을 따라 절리가 발달해 있는데, 이 절리 를 따라 풍화와 침식이 계속 진행되고 있는 것을 관 찰할 수 있다. 또한 탑사 관리사무소를 지나 은수사 뒤쪽 수마이산을 바라보면서 화엄굴까지 가다보면 수 직으로 발달한 거대한 절리들을 쉽게 볼 수 있다. 이 수직 절리를 따라 역이 빠지면서 풍화와 침식이 일 어나고, 계속해서 그 주변으로 틈이 확대되고 있으며, 일부 절리의 아래 부분에서는 커다란 동굴이 형성되 고 있는 것을 관찰할 수 있다.

마이산 남부와 북부의 풍화와 침식(N35 $45^{\prime} 40.8^{\prime \prime}$, $\left.\mathrm{E} 127^{\circ} 24^{\prime} 54.7^{\prime \prime}\right)$ : 진안읍 방향에서 마이산 북쪽 사면을 바라보면 말귀를 닮은 모습을 볼 수 있다. 마이산 북 쪽 사면은 남쪽 사면에서 흔하게 관찰되는 타포니가 나타나지 않는다. 이는 마이산 북쪽과 남쪽 사면에서 받는 태양에너지양과 관계가 있는 것으로 해석된다. 남쪽 사면은 빙하기 또는 온도가 낮은 겨울 동안 결 빙과 해빙이 반복되면서 역암을 이루고 있는 역들이 쉽게 떨어져 나오면서 타포니가 발달된다. 반면, 북 쪽 사면은 온도 변화가 적어 타포니가 형성되기 어 려웠을 것으로 해석된다.

\section{관찰지점 3: 마령면 동촌리 일대}

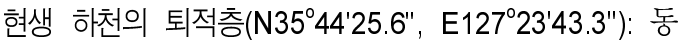
촌리 비리소골에 있는 소규모 저수지 앞을 흐르는 하천에서 현생 퇴적층의 단면이 잘 나타나 있다. 평 상시에는 수량이 많지 않으나 홍수 시기에는 수량이 풍부한 곳이다. 하천을 따라 약 $100 \mathrm{~m}$ 의 현생 퇴적 층 노두에서 역암, 역질사암 및 사암이 형성되고 있 는 과정과 퇴적구조를 관찰할 수 있다(Fig 10). 맨 아래층에서 형성되고 있는 역암은 분급은 다소 불량 하나 원마도는 아주 양호하며, 역들이 물의 흐름 방 향으로 배열되어 있는 층리면(bedding plane)과 비늘 구조(imbrication)가 보인다. 또한 현생 역암을 구성하 고 있는 역의 종류는 마이산 일대 암석에서 풍화 침 식되어 운반된 규암, 편암, 화강암, 편마암, 화산암류 등으로 이루어져 있으며, 역의 크기도 다양하다. 역 질사암 및 사암층도 잘 형성되고 있으나 층리는 잘 보이지 않는다. 이곳에서 형성되고 있는 현생 퇴적층 과 퇴적구조를 통해서 고생 퇴적암 및 퇴적구조의 형성과정을 이해할 수 있다.
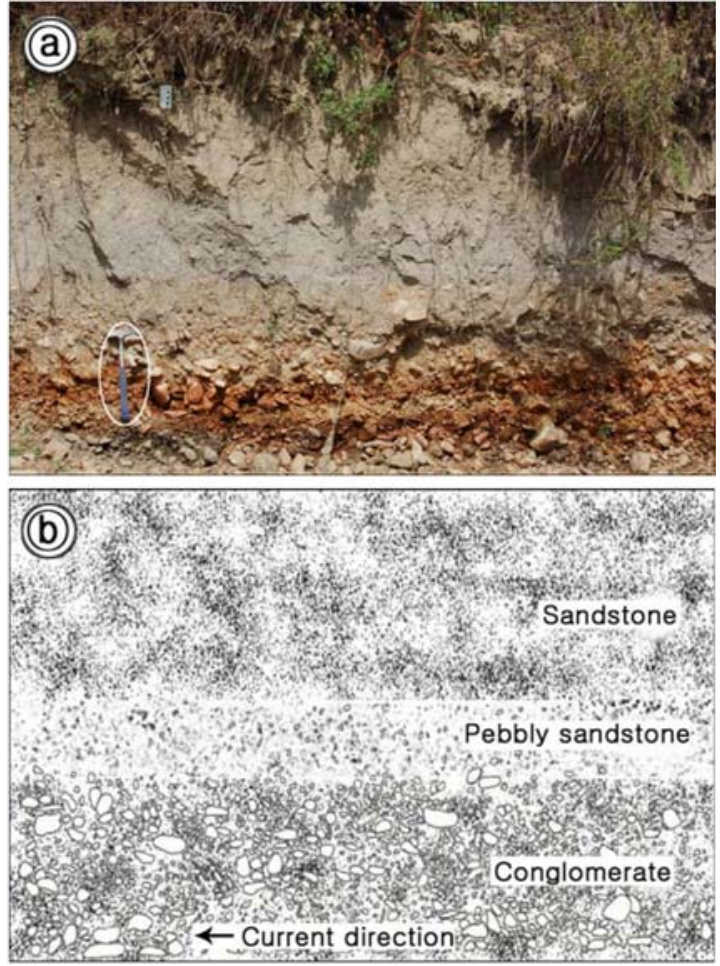

Fig. 10. Photograph (a) and sketch (b) of sedimentary succession of Quaternary formed in a modern fluvial stream. Scale for a $30-\mathrm{cm}$ hammer. An arrow indicates the direction of paleocurrent in the exposure.

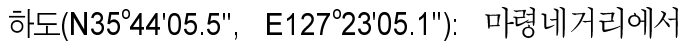
30 번 도로를 타고 진안 방향으로 동촌교 부근에 노 두가 있다. 이암과 이암 사이에 역질사암층의 돌출부 가 발견되는데 이것이 바로 하도(channel)이다. 이곳 은 마이산 지역과 달리 역질사암, 사암 및 이암으로 구성되어 있는 것으로 보아 퇴적 분지 경계부(상류 방향)에서 분지 안쪽(하류 방향)으로 들어온 지역이 었음을 유추할 수 있다.

\section{관찰지점 4: 평지리 앞 하천}

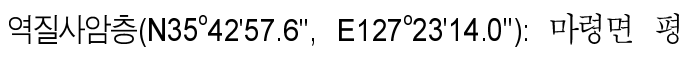
지리에서 백운 방향의 평지리 하천입구에서 노두를 발견할 수 있다(Fig. 11). 이 노두는 하부로부터 이암, 역질사암, 이암, 사암, 역질사암 층이 반복되는 형태 를 보인다. 이 퇴적층은 분지 경계부(상류)보다 분지 안쪽(하류)에서 형성된 것으로 생각되며, 역질사암으 로 충전된 하도를 볼 수 있다. 


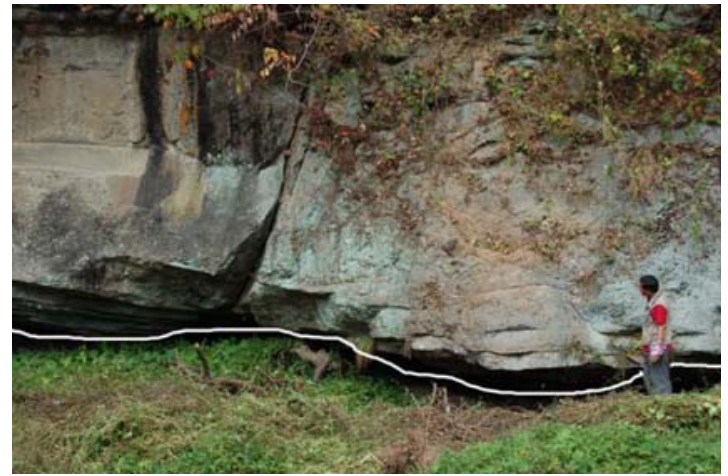

Fig. 11. Photograph of scour-and-fill channel fills comprising mudstone, sandstone, and pebbly sandstone beds. White line indicates distinct scour surface in the lower part of the channel fills. Scale for a person.

길버트형 삼각주(N35 $\left.42^{\prime} 45.8^{\prime \prime}, \mathrm{E} 127^{\circ} 23^{\prime} 37.1^{\prime \prime}\right)$ : 마령 면 평지리 앞 하천 둑을 따라 백마교 쪽으로 가다보 면 산 중턱에 만추정 정자가 나오는데, 그 아래에 남 서쪽에서 북동쪽으로 여러 겹으로 경사져 있고, 길이 가 약 $50 \mathrm{~m}$ 이고, 두께는 약 $9 \mathrm{~m}$ 되는 퇴적층을 발견 할 수 있다. 이 지층은 지각 변동을 받아서 경사져 있는 것이 아니라 퇴적 당시의 환경에서 형성된 길 버트형 삼각주(Gilbert-type delta) 층이다(Fig. 12). 길 버트형 삼각주에서 윗 부분을 표면층(topset), 가운데 부분을 전면층(foreset), 그리고 아래쪽 부분을 기저층 (bottomset)이라고 부른다. 길버트형 삼각주의 형성은 하천에서 볼 수 있는 사층리와는 다르다. 이는 진안 분지가 형성될 당시 호수면이 안정적이면서 깊고, 충 분한 퇴적물이 공급되어 퇴적층이 전진하면서 형성된 것이다. 이 퇴적층의 전진 방향이 퇴적이 될 때 퇴적

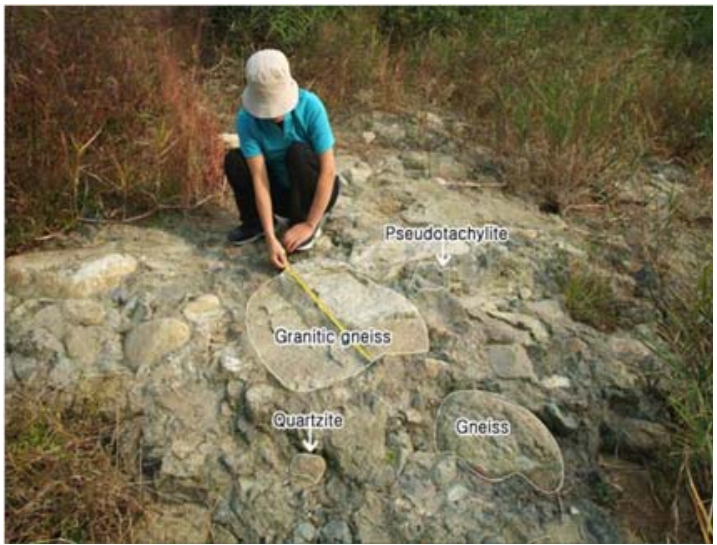

Fig. 13. Photograph of pebble- to boulder-grade clast-supported disorganized conglomerate of gneiss, quartzite, pseudotachylite clasts in the basin margin. Scale for a person.

물의 이동을 나타내는 고수류 방향임을 알 수 있다.

\section{관찰지점 $5:$ 진안분지의 북동 경계부}

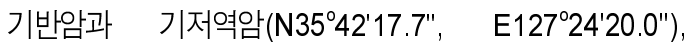

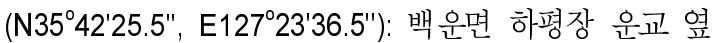
야산에는 기반암인 편마암이 노출되어 있다. 분지 주 변의 기반암을 조사하면 분지 내 역암의 역들과 비 교해 볼 수 있다. 이 과정을 거쳐 분지 내에 분포하 고 있는 역들의 공급지를 알 수 있다. 또한 마령면 방화마을에서 백운면 하평장 가는 도중 백마교가 나 오는데, 백마교에서 하천을 따라 약 $300 \mathrm{~m}$ 남쪽 방 향으로 가면 수중보가 나온다. 수중보 주변의 하천 바닥과 산사면에서 역암을 관찰할 수 있다(Fig. 13). 이 지역은 분지 경계부로 역의 크기가 다양하며, 역

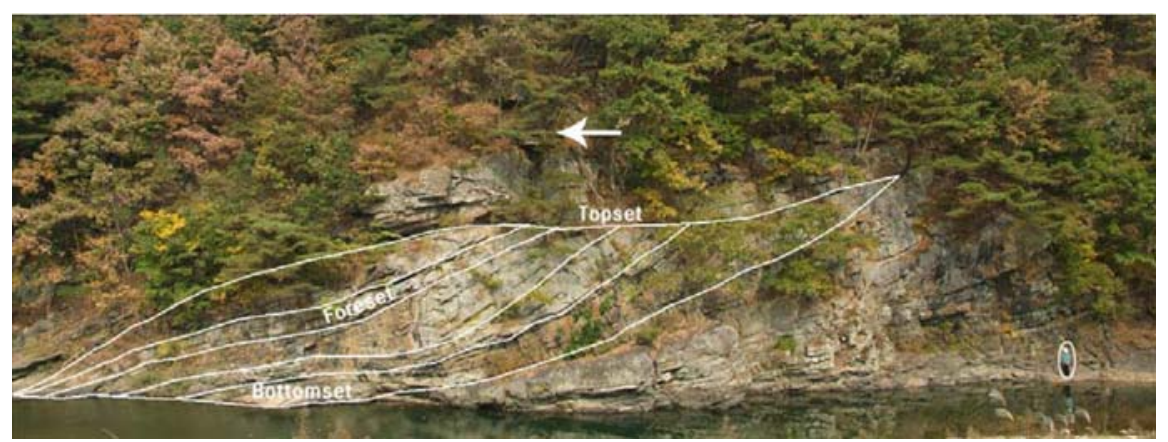

Fig. 12. Photograph with line drawing of Gilbert-type delta sequences showing tripartite geometry of topset, foreset, and bottomset strata. The section is parallel to paleoflow direction and an arrow marks the paleocurrent direction. Note several stacks of small-scale, Gilbert-type delta sequences. Scale for a person. 
의 종류도 편마암, 규암, 편암, 슈도타킬라이트 등으 로 이루어져 있다.

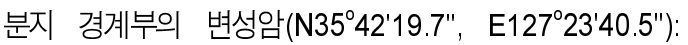
백운면 지동마을 옆 야산과 하천 바닥은 분지 경계 부로 기반암인 규암층, 그리고 분지 경계지역에서 단 층이 일어나면서 형성된 압쇄암(mylonite)과 검은색 의 슈도타킬라이트(pseudotachylite)가 발견된다. 단층 대에서 단층의 파쇄작용에 의해 형성되는 파쇄암은 압쇄암, 슈도타킬라이트, 안구 편마암(augen gneiss)이 있다. 압쇄암의 조성은 압쇄되기 이전의 암석의 종류 에 따라 다르며, 특징은 몹시 부서진 듯한 느낌과 입 자들이 길게 신장되어 갈린 듯한 모습을 보이며, 형 성 환경은 습곡 및 단층 등에 의한 미끄러짐에 의해 부서져서 생성된다. 슈도타킬라이트의 조성은 압쇄되 기 이전의 암석의 종류에 따라 다르며, 특징으로는 대개 검은색을 띠며, 활면을 따라 세맥상으로 관입한 것처럼 보인다. 또한 슈도타킬라이트의 형성 환경은 주로 물이 없는 건조한 환경에서 습곡 및 단층 등에 의해 암석이 미끄러질 때 순간적으로 높은 열이 발 생하여 부분 용융이 일어나고 이 용융물이 주변의 암석을 뜷고 들어가서 형성된다.

\section{결과 및 토의}

마이산 일대 다섯 곳에서 야외지질 학습자료 및 체험학습장 개발 결과는 다음과 같다.

관찰지점 1 에서는 퇴적암의 특징 및 종류, 지질구 조를, 관찰지점 2 에서는 역암의 층리면과 역의 종류, 풍화와 침식을, 관찰지점 3 에서는 현생 퇴적층에서 일어나는 퇴적구조와 퇴적암의 형성, 하도에 대하여, 관찰지점 4 에서는 역질사암과 길버트형 삼각주, 관찰 지점 5 에서는 분지 주변의 기반암과 기저역암 등에 대하여 학습자료와 체험학습장을 개발하였다. 과학교 과 학습에서 아이들의 과학적 태도와 창의성을 신장 시키기 위해서는 야외지질 체험학습과 같은 다양한 활동이 필요하다. 그래서 초등 과학 교과서를 분석하 여 3-6학년 담당 교사들에게 지구과학 지질관련 내용 에 대한 지식, 이해도, 수업하기 어려운 내용 등을 알아보았다. 그 결과 초등 교사들은 초등 과학 교과 서 지구과학 분야인 지질관련 내용에 대한 수업 진 행과정에서 큰 어려움을 겪고 있는 것으로 나타났다. 이러한 어려움을 해결하기 위해서는 초등 교사들이
야외 지질에 대한 경험이 중요하다. 따라서 본 연구 는 마이산 일대를 중심으로 야외지질 학습자료와 체 험학습장을 개발하여 13 명의 초등교사들에게 적용하 였으며 반응은 다음과 같다.

진안농공단지 뒤쪽 거북이바위에서 퇴적암, 퇴적구 조 및 지질구조를 관찰하였는데, 이암, 사암, 역암은 대부분의 교사들이 구분하였다. "이렇게 암석이 크고 넓게 쌓여있는가요? 처음 보았어요.”라는 질문을 받 았는데, 이는 초등학교에서 암석원이나 상자 안에 들 어있는 암석 샘플만을 주로 보고 다루었으며 큰 규 모의 암석층은 보지 못했기 때문이다. 또한 셰일에서 나무줄기의 파편 화석을 관찰하였는데, "아니 이것도 화석이나요?" "너무 시시해요."라는 반응을 보였다. 화석을 직접 본 적이 있는가를 확인했는데 대부분의 교사들은 화석박물관이나 과학관 등에서 주로 완전하 게 보존된 화석을 보아서 완전한 형태의 화석만이 화석이라는 고정관념을 가지게 된 것으로 생각된다. 그래서 실제 지층에서 발견 되는 화석이 파편이나 흔적으로 더 많이 발견되고 있다는 사실을 인지하지 못한 셈이다. 대부분의 교사들이 야외지층에서 단층 을 직접 본 것은 처음이어서 정단층인지를 구분하기 는 어려웠지만 단층의 형성과정은 이론적으로는 설명 할 수 있었다. 그러나 모든 교사들이 단층면에서 나 타나는 “단층경면이나 단층점토는 처음 보았어요."라 고 답하였다.

탑사 주변에서는 타포니(taponi)의 풍화 과정과 절 리를 따라 진행되는 풍화와 침식은 쉽게 이해하였다. “역암층에서 층리는 어떻게 찾을 수 있을까요?"라는 질문에는 대부분이 층리를 찾지 못했지만 층리면 (bedding plane)을 설명하자 대부분이 이해하였다. 몇 명의 교사는 “어떻게 역암이 큰 암석 덩어리로 만들 어질 수 있는지요? 이해가 안가요.”라고 질문을 하였 다. 역암을 구성하고 있는 역의 종류에 대해서는 대 부분이 구별하지 못했다.

비리소골 일대 현생 퇴적층 관찰에서는 퇴적암의 형성과정과 퇴적구조, 수류 방향을 쉽게 이해하였다. 하지만 마령 네거리에서 동촌교 사이 도로가에서 보 이는 하도(channel)는 모두가 처음 보았다고 하였다. 몇 선생님은 “하도가 뭐지요?”라는 질문을 하였고 설 명을 하자 그런데 “어떻게 저런 구조로 나타나죠?" 다시 질문을 하여 퇴적층 노두의 절삭면에 따라 형태 가 다르게 보이는 것을 설명하자 충분히 이해하였다.

평지리 하천 일대의 역질사암, 사암, 이암 층이 반 
복되어 있는 것을 찾을 수 있었는데, 그런데 "왜 마이 산과 같은 역암은 없어요?"라는 질문을 받았다. 이에 퇴적물의 크기와 이동거리에 대해 설명하고, "이곳이 과거에 마이산 역암층에 비해 상류 방향일까요? 하류 방향일까요?"라는 질문을 하자 바로 이해하지 못했지 만, 퇴적물의 운반 등에 관해 설명하자 하류 방향이라 는 것을 대부분이 이해하였다. 하천과 나란히 쌓여 있 는 길버트형 삼각주(Gilbert-type delta)를 보고서 “지 층이 왜 저렇게 기울어졌을까요?”라는 질문을 하였더 니 모두가 지각변동에 의해 기울어졌다고 대답하였다. 이에 지각변동에 의해 지층이 경사진 것이 아니라 전 진퇴적에 의해 형성된 지층으로 퇴적 당시의 퇴적환 경을 그대로 간직하고 있다는 것을 설명하자 이해하 였다. "저 길버트형 삼각주를 보면서 퇴적 당시 물의 흐름 방향을 알 수 있을까요?"라는 물음에는 전진 퇴 적과 같은 방향이라고 쉽게 대답하였다.

지동일대 분지 경계의 기반암인 편마암은 풍화가 되어 아무도 구분하지 못했다. 단층대에서 형성된 압 쇄암이나 슈도타킬라이트도 처음 접한 암석이라 형성 과정과 특징을 설명하였지만 잘 이해하지 못했다. 분 지경계의 역암에 대해서 역의 크기, 원마도, 역의 종 류를 구분하도록 하였다. 일부 교사는 잠시 전에 보 았던 슈도타킬라이트나 편마암 등을 구분하였고, "왜 역의 크기가 이렇게 크고 원마도가 불량 할까요?”라 는 질문에는 대다수의 교사가 "분지 가장자리이기 때 문이지요.”라고 대답하였다. 이는 앞서 탑사 주변의 마이산 역암층 탐사에서 분지에 대한 설명을 들었기 때문이다.

대부분의 초등 교사들은 야외지질 탐사활동을 처음
경험하였다. 탐사 활동 과정에서 생활 주변이나 과학 관 등에서 자주 보고 접한 내용은 쉽게 알았고, 처음 으로 접한 노두에 대해서는 잘 몰랐지만 상호 질문 과 설명을 통해서 잘 이해하였다. 일부 교사는 과학 관에서 완전한 형태를 갖춘 화석만을 보았고, 야외 지층에서 파편이나 흔적 등 다양한 형태로 발견되는 것은 처음 보았다. 교사들은 마이산 일대의 탐사 활 동 과정에서 많은 것을 경험하였고, 야외지질 학습이 중요하다는 의견을 제시하였다. 이같이 주변에서 쉽 게 접할 수 있는 노두에서 초등교사들이 야외지질 탐사 활동을 지속적으로 실시한다면 야외지질 체험학 습을 진행하는데 많은 도움이 될 것이다.

대다수의 초등 학생들은 과학의 개념에 대해 발명, 실험, 관찰 등으로 파악하고 있어 활동 중심의 과학 관을 지니고 있지만 과학은 학교에서만 하는 것이라 는 인식이 지배적이다(김정화 외, 2002). 또한 과학을 재미있고 좋아하지만 과학자가 되겠다는 학생은 소수 이며, 학년이 높아질수록 선호도가 낮아지며 과학자 가 되고 싶다는 반응도 낮다(김정화 외, 2002). 이는 학년이 높아질수록 이론 중심의 수업과 문제 풀이식 학습의 영향이라고 생각되기 때문에 교사들은 다양한 활동을 통하여 학생들이 흥미를 가질 수 있는 다양 한 야외 학습을 지속적으로 실시해야 한다. 교사는 내용학적인 지식을 적절한 교육학적인 기능을 통하여 학생들에게 전이시키는 과학 교과교육학 지식이 높을 수록 지식을 충분히 활용하고, 수업에 상당한 자신감 과 자긍심을 가지고 있기 때문에(임청환, 2003), 야외 지질 학습을 위해서는 지질관련 내용의 지식을 풍부 하게 함양해야 한다. 특히 초등학교에서 과학 탐구

Table 2. Responses of the teachers who participated in a geological fieldwork (1) strong denial, (2) denial, (3) just so, (4) affirmation, and (5) strong affirmation, $\mathrm{N}=13$ )

\begin{tabular}{|c|c|c|c|c|c|c|}
\hline \multirow{2}{*}{ Section } & \multirow{2}{*}{ Item } & \multirow{2}{*}{ Statements } & \multicolumn{4}{|c|}{ Number of response } \\
\hline & & & (1) (2) & (3) & (4) & (5) \\
\hline \multirow{3}{*}{$\begin{array}{l}\text { Benefits of geological } \\
\text { fieldwork }\end{array}$} & 1 & Geological fieldwork was useful for experiencing various geologic phenomenon. & & & 7 & 6 \\
\hline & 2 & I want to participate in geological fieldwork activity in future. & & & 6 & 7 \\
\hline & 3 & I got some confidence for geological contents after geological fieldwork activity. & & 1 & 6 & 6 \\
\hline \multirow{2}{*}{ Utilization for class } & 4 & Geological fieldwork is important for students. & & 1 & 5 & 7 \\
\hline & 5 & Geological fieldwork is helpful in teaching lessons of geological contents. & & 1 & 7 & 5 \\
\hline Fieldwork sites & 6 & Geological fieldwork sites and materials should be developed variously. & & & 1 & 12 \\
\hline \multirow{2}{*}{$\begin{array}{l}\text { Training and geological } \\
\text { fieldwork }\end{array}$} & 7 & Systematic theoretical training course for geological contents is necessary. & & & 6 & 7 \\
\hline & 8 & Geological fieldwork for teachers should be held often. & & & 2 & 11 \\
\hline $\begin{array}{l}\text { Utilization of } \\
\text { fieldwork sites }\end{array}$ & 9 & $\begin{array}{l}\text { I will organize geological fieldwork in Mt. Mai afterward and explain } \\
\text { geological phenomenon for students. }\end{array}$ & & & 5 & 8 \\
\hline
\end{tabular}


수업 실행의 저해요인은 교사들의 탐구 경험 부족으 로 인한 심리적 자신감 결여와 교사들에게 적절하게 적용될 수 있는 탐구지도 자료의 개발 및 연구 부족 이다(조현준 외, 2008).

본 연구에서는 야외지질 탐사 활동에 참가한 13 명 모두는 야외지질 체험학습이 매우 중요하다는 의견을 개진하였고, 대다수의 교사가 탐사활동 후 지질관련 단원 수업에 도움이 되고 있으며 자신감을 가졌다고 응답하였다. 또한 초등 교사를 위한 다양한 야외지질 학습자료와 체험학습장 개발, 지속적인 탐사 활동, 연수 등의 필요성을 강조하였다(Table 2).

\section{결론 및 제언}

전라북도 진안군에 있는 마이산은 많은 학생들과 일반인들이 찾는 관광지일 뿐만 아니라 다양한 지질 내용을 포함하고 있는 노두가 있어 야외지질 학습을 실시하기 적절한 장소이다. 따라서 본 연구는 마이산 일대를 중심으로 야외지질 학습자료를 개발하였다. 초등학교에서는 일 년에 한두 번 관광지를 중심으로 현장 체험학습을 실시하고 있다. 지금까지 마이산 일 대는 양질의 지질관련 노두가 있는 학습터 임에도 불구하고 풍경만을 감상하는 관광위주의 활동장소로 인식되었다. 이는 지질에 대한 초등 교사들의 배경지 식 및 야외지질에 대한 경험 부족, 초등학생들을 위 한 야외지질 체험학습장의 부족 때문이다. 초등학생 들에 대한 야외지질 학습을 활성화시키기 위해서는 다양한 학습장 개발과 초등 교사들의 탐사 활동의 경험이 반드시 필요하다. 본 연구에서 초등학교 교사 들을 대상으로 탐사 활동을 실시한 결과, 대부분의 초등 교사들은 야외지질 체험학습이 매우 유용하며, 다양한 지질현상을 이해하는데 많은 도움이 되었고, 지질관련 단원 수업을 하는데 자신감을 갖게 되었으 며, 교과 교육 활동에 도움이 될 것이라는 반응을 보 였다. 이 같은 결론을 수용하여 교육기관은 교사들이 자신감을 가지고 야외지질 체험학습을 진행할 수 있 도록 많은 야외지질 학습장과 자료를 개발하고, 다양 한 연수를 통해 야외지질 탐사 활동의 기회를 지속 적으로 제공하는 것이 바람직하다.

\section{사 사}

논문심사와 함께 논문의 부족한 부분을 세심하게
지적해 주신 조선대 신인현 교수님과 익명의 두 분 심사자께 감사드립니다. 야외와 실내에서 함께 조사 와 토론을 해 주신 박재문, 소광석 선생님과 정덕호 교수님께 감사드립니다. 전북지역 야외학습장 자료개 발을 위해 도움을 주신 전북 교육청과 전북대 과학 교육연구소 안병준 교수님께 감사드립니다.

\section{참고문헌}

김규봉, 최위찬, 황재하, 김정환, 1984 , 한국지질도 $(1: 50,000)$, 오수도폭 및 설명서. 한국동력자원연구소, $38 \mathrm{p}$.

교육인적자원부, 2007 , 초등학교교육과정: 교육인적자원부 고시 제2007-79호(별책 02). 교육인적자원부, 296 p.

김정화, 조부경, 2002 , 유치원과 초등학교 학생의 과학 및 과학활동에 대한 인식. 한국과학교육학회지, 22,617 631.

서동욱, 2004 , 야외 지질 학습장의 퇴적암과 지질 구조에 관한 초등학생들의 관찰 및 가설 분석. 한국지구과학회 지, $25,586-594$.

교육과학기술부, 2009 , 초등학교 교사용지도서 과학 6-1. 금성출판사, 서울, $192 \mathrm{p}$.

곽영순, 2003 , 좋은 수업을 하는 현장 교사들이 제안한 과 학 교사교육 개선방안. 한국지구과학회지, 24, 117-127.

맹승호, 2004 , 야외 지질 학습 수업모형에 관한 고찰. 함께 하는 지구과학교육, 3, 55-64.

맹승호, 박명숙, 이정아, 김찬종, 2007 , 야외 지질 학습에서 나타난 중학생들의 귀추적 추론 사례 연구. 한국교육과 학회지, 27, 818-831.

박경화, 조규성, 양우헌, 김은주, 2006 , 전북지역 자연생태 탐구학습자료 개발. 전북대학교과학교육연구소, 96 p.

박재문, 양우헌, 조규성, 2007 , 전북 부안군 채석강 일대의 야외지질 학습자료 개발 및 적용. 한국지구과학회지, 28, 747-761.

손치무, 1969 , 한국의 지각변동에 관하여. 지질학회지, 5 , 167-210.

양일호, 김석민, 조현준, 2997 , 초- 중등학교 과학 실험수업 의 유형 분석. 한국교육과학회지, 27, 235-241.

유인창, 김부용, 곽원준, 김기현, 박세진, 2000 , 황해 및 인 접 지역 퇴적분지들의 구조적 진화에 따른 층서. 한국 석유지질학회지, 8, 1-43.

이병주, 노병섭, 이한조, 최재훈, 2005 , 전북 지역의 지질학 습장 개발과 이용을 위한 지도교사 워크샵 안내 자료. 지구를사랑하는사람들, 전주, 33 p.

이영엽, 1992 , 백악기 진안분지의 층서, 퇴적환경 및 진화 에 관한 연구. 서울대학교박사학위논문, $287 \mathrm{p}$.

임청환, 2003 , 초등교사의 과학 교과교육학 지식의 발달이 과학 교수 실제와 교수 효능감에 미치는 영향. 한국지 구과학회지, 24, 258-272.

조규성, 변흥룡, 김정빈, 2002 , 야외지질학습장의 개발과 활 용에 따른 학생들의 과학에 대한 정의적 영역과 학업 성취에 미치는 효과. 한국지구과학회지, 23, 649-658. 
조현준, 한인경, 김효남, 양일호, 2008 , 초등학교 과학 탐구 수업 실행의 저해 요인에 대한 교사들의 인식 분석. 한 국과학교육학회지, 28, 901-921.

한국자원연구소, 1995 , 한국지질도 $(1: 1,000,000)$. 성지문화 사.

허명, 1993, 초중고 학생의 과학 및 과학교과에 대한 태도 조사 연구. 한국과학교육학회지, 17, 85-92.

홍만섭, 윤선, 길영준, 1966 , 한국지질도(1:50,000), 갈담 도 폭 및 설명서. 국립지질조사소, $21 \mathrm{p}$.

Baag, C.B. and Baag, C.E., 1994, Aeromagnetic interpretation of the southern and western offshore Korea. Korean Society of Petroleum Geology, 2, 51-57.

Choi, H.I., 1986, Sedimentation and evolution of the Cretaceous Gyeongsang Basin, southeastern Korea. Journal of the Geological Society, London, 143, 29-40.

Chough, S.K., Kwon, S.-T., Ree, J.-H., and Choi, D.K., 2000, Tectonic and sedimentary evolution of the Korean Peninsula: A review and new view. Earth Science Reviews, 52, 175-235.

Chun, S.S. and Chough, S.K., 1992, Tectonic history of Cretaceous sedimentary basins in the southeastern Korean Peninsula and Yellow Sea. In Chough, S.K. (eds.), Sedimentary Basins in the Korean Peninsula and Adjacent Seas. Korean Sedimentology Research Group, Special Publication, Seoul, 60-76.

Kim, J.H. and Kee, W.S., 1994, Structural characteristics of the Soonchang Shear Zone, Korea. Journal of South- east Asian Earth Science, 9, 417-428.

Lee, S.H., 1995, Depositional architecture in the eastern part of Jinan Basin (Cretaceous), SW: Depositional model for differential along the strike-slip margin. M.S. Thesis, Seoul National University, Seoul, Korea, 147 p.

Lee, S.H. and Chough, S.K., 1999, Progressive changes in sedimentary facies and stratal patterns along the strikeslip margin, northeastern Jinan Basin (Cretaceous), Southwest Korea: implications for differential subsidence. Sedimentary Geology, 123, 81-102.

Manner, B.M., 1995, Field studies benefit students and Teachers. Journal of Geological Education, 43, 128-131.

Orion, N., 1989, Development of high school geology course based on field trips. Journal of Geological Education, 37, 13-17.

Ryang, W.H., 2005, Channel-fill deposits of gravel-bed stream, southeastern Eumsung Basin (Cretaceous), Korea. The Journal of the Korean Earth Science Society, 27, 757-767.

Ryang, W.H. and Chough, S.K., 1999, Alluvial-to-lacustrine systems in a pull-apart margin: Southwestern Eumsung Basin (Cretaceous), Korea. Sedimentary Geology, 127, 31-46.

Shimamura, S., 1925, Geological atlas of Chosen (Korea), no. 5, Jinan and Cheonju sheets (1:50,000). Geology Survey of Korea, 5 p. 